\title{
Внесок дипломатичного корпусу Гетьманату в реалізацію геополітичної стратегії Павла Скоропадського
}

\author{
Приходько М. М., Національний педагогічний університет ім. М. П. Драгоманова
}

За допомогою комплексу робіт проведено дослідження основних умов та аспектів практичної реалізації програми формування міждержавних відносин між Українською Державою гетьмана Павла Скоропадського та країн Четверного Союзу. Особлива увага в статті приділена діяльності дипломатичної місії у Відні, завданням якої була практична реалізація австро-угорського вектору зовнішньополітичної стратегії Української Держави.

В статті проаналізовано спроби встановлення та розширення зв'язків із Болгарським Царством та Османською Імперією, протистояння територіальним претензіям Румунії та Польщі.

Окремо висвітлено процес реалізації геополітичної стратегії гетьманської держави головами дипломатичних місій: в Болгарському царстві - О. Шульгіним, в Австро-Угорщині - В. Липинським та М. Левитським, першим тимчасовим представником України в Туреччині.

Аналіз матеріалів із досліджуваної теми дозволяє констатувати, що активність дипломатичного корпусу Української Держави в даному напрямку дійсно принесла велику користь для становлення молодої держави в тих умовах, в яких відбулося іії формування.

Ключові слова: Перша світова війна; Українська Держава; гетьманський уряд; Четверний Союз; дипломатія; зовнішня політика; геополітика

\section{Contribution of the Hetmanate's diplomatic corps in implementing the geopolitical strategy of Pavlo Skoropadsky}

\section{Prykhodko M. M., National Pedagogical Dragomanov University}

We analyzed the main conditions and aspects of practical implementation of intergovernmental relations of the Ukrainian Hetman state in the context of foreign policy connected with West European direction.

We characterized the division of the directions of interstate relations into four groups. The first group includes relations with Germany and Austria-Hungary. The second group includes relations with the countries and state formations that appeared in the territory of the Russian Empire after its collapse. The third group includes Romania and Poland. The common feature of these countries should be the presence of territorial claims and ambitions of both states in relation to Ukraine and the restoration of its historic grandeur. The countries of the Quadruple Alliance and neutral countries of Europe are included to the fourth group.

We made an important conclusion that the main export potential and the main factor influencing the countries of the Quadruple Alliance of the Ukrainian State were military goods, arms, ammunition and food.

We highlighted a number of shortcomings in the geopolitical strategy of Hetman Skoropadsky's government. Firstly, it is excessive concentration on the German and Austro-Hungarian vectors, the lack of development of relations with neutral countries in order to attract additional capital to the Ukrainian economy. Secondly, significant outflows of capital from the Entente countries, which were invested in the industrial sector during the time of the Ukrainian People's Republic is also considerable.

We think that the analysis of the practical geopolitical strategy of Hetman Pavlo Skoropadsky by the diplomatic corps of the Ukrainian State makes positive conclusions regarding the quality and quantity of established diplomatic communications.

We looked into the question of the priority orientation on the countries of the Quadruple Alliance from the part of Hetman Skoropadsky, who tried to develop diplomatic relations with neighboring countries, including the states formed on the territory of the Russian Empire after its collapse.

We found that the attempts of the Ministry of Foreign Affairs and the diplomatic corps of the Ukrainian State of Hetman Pavlo Skoropadsky were connected with permanent international communication with 10 countries. Besides, temporary diplomatic missions were sent to more than 20 countries during this period. The delay in the establishment of diplomatic relations with Entente countries should be considered as a disadvantage of the geopolitical strategy of Hetman Skoropadsky, which can be explained by the active opposition of the diplomatic corps of Germany and Austria-Hungary.

Keywords: First World War; Ukrainian State; hetman's government; Fourth Union; diplomacy; foreign policy; geopolicy 


\section{Вклад дипломатического корпуса Гетманата в реализацию геополитической стратегии}

\section{Приходько Н. Н., Национальный педагогический университет им. М. П. Драгоманова}

С помощью комплекса работ проведено исследование основных условий и аспектов практической реализации программы формирования межгосударственных отношений между Украинским Государством гетмана Павла Скоропадского и стран Четверного Союза. Особое внимание в статье уделено деятельности дипломатической миссии в Вене, задачей которой была практическая реализация австро-венгерского вектора внешнеполитической стратегии Украинского Государства.

В статье проанализированы попытки установления и расширения связей с Болгарским царством и Османской Империей, противостояние территориальным претензиям Румынии и Польши.

Отдельно освещены процесс реализации геополитической стратегии гетманского государства главами дипломатических миссий: в Болгарском царстве - А. Шульгиным, в Австро-Венгрии - В. Липинским и М. Левитским, первым временным представителем Украины в Турции.

Анализ материалов по исследуемой теме позволяет констатировать, что активность дипломатического корпуса Украинского государства в данном направлении действительно принесла большую пользу для становления молодого государства в тех условиях, в которых произошло ее формирование.

Ключевые слова: Первая мировая война; Украинское Государство; гетманское правительство; Четверной Союз; дипломатия; внешняя политика; геополитика

\section{Постановка проблеми.}

$\Pi$ еріод існування Української Держави кінця квітня - початку грудня 1918 p. $є$ особливо цікавим своєю складністю. Українська Держава була одним із можливих образів нової України, яка відновлювала свою незалежність і навколо чого точилася боротьба внутрішніх сил. За своєю інтенсивністю ця боротьба набувала форм гострого громадянського конфлікту, що відповідало умовам Української революції 1917-1921 pр. Із цієї точки зору геополітичне позиціонування України, яким його бачили гетьман Павло Скоропадський та його прибічники, було частиною консервативного проекту Української революції.

\section{Аналіз досліджень і публікацій.}

У новітній вітчизняній історіографії було проведено своєрідну «реабілітацію» Української Держави та іiі провідних діячів. Було проведено низку вагомих конференцій, присвячених проблемам осмислення історії Української Держави і особистостей іiі провідників та ідеологів, формування дипломатичного корпусу, створення дієвого механізму реалізаціііі зовнішньої політики.

Зокрема, цілий пласт досліджень із даної тематики було оприлюднено на II Міжнародній науковій конференції «Гетьман Павло Скоропадський та Українська Держава 1918 року» (1998р.), Всеукраїнських наукових читаннях пам'яті В'ячеслава Липинського 3 нагоди 120-річчя 3 дня народження $(2002$ р.), Всеукраїнській науковій конференції «Гетьманат Павла Скоропадського: історія, постаті, контроверсії» (2008р.), Всеукраїнській науковій конференції «Павло Скоропадський останній гетьман України (до 95-річчя Української Держави та 140-річчя від дня народження Павла Скоропадського)» (2013 р.).

Були видані збірки «Останній гетьман.
Ювілейний збірник пам'яті Павла Скоропадського» [1] та «Гетьман Павло Скоропадський та Українська Держава 1918 року. Наук. зб. присвячений 125-річчю від дня народження П. Скоропадського та 80-річчю проголошення Української держави» [2], «Павло Скоропадський - останній гетьман України (до 140-річчя від дня народження)» [3].

Метою роботи є висвітлення внеску дипломатичного корпусу Гетьманату в реалізацію геополітичної стратегії П. Скоропадського.

\section{Виклад основного матеріалу.}

Важливим напрямком геополітичної стратегії Гетьмана П. Скоропадського слід вважати вирішення так званого Західноукраїнського питання. Воно полягало у двох аспектах:

встановлення дипломатичних зв'язків із Австро-Угорщиною 3 метою ратифікації нею Брестського мирного договору, а також $з$ метою визнання останньою Української Держави;

- встановлення суверенітету Української Держави на територіях розселення етнічних українців на Західній Україні, землі якої перебували у складі, під протекторатом чи в інший спосіб підпорядковувались Австро-Угорщині.

Реалізація і першого, i другого напрямку зовнішньої політики Української Держави багато в чому залежала від дипломатичної майстерності та досвіду українського посла у Відні.

Т. Осташко з цього приводу зауважує, що «уряд П. Скоропадського намагався уладнати взаємини 3 Австро-Угорщиною, причому діяв досить рішуче й наполегливо. Між іншим, Відень від самого початку приходу гетьмана П. Скоропадського до влади ставився до нього 3 пересторогою. Він дуже болісно відреагував на титул «Гетьман усієї України», який номінально поширював його владу також на українські землі у складі Габсбурзької 
монархії. У листах до Києва В. Липинський пропонував урядові і Міністерству закордонних справ рішучіше відстоювати право на українські землі й вимагати ратифікації та виконання Віднем Брестських угод. Він пропонував не лише висловлювати ноти протесту, а й погрожувати припиненням поставок хліба й навіть відкликанням посольства 3 Відня, тобто розривом дипломатичних відносин» [4, с. 657]. «Українське посольство в Австрії мало першорозрядний статус. Призначення послом у Відні В. Липинського було свідченням великого значення, яке надавала Українська Держава політичним стосункам 3 Австро-Угорщиною. Це був ключовий дипломатичний напрям 3 огляду на те, що саме Австро-Угорщина мала в своєму складі укحраїнські й польські землі, що вимагало тут від України особливо сильної і активної дипломатії. Обізнаність В. Липинського з польською проблемою, його авторитет у впливових галицьких колах і серед українців державницької орієнтації свідчили про те, що він є найбільш вдалою кандидатурою на цю важливу дипломатичну посаду» $[5$, с. 325$]$.

Л. Білас у своїх дослідженнях зауважував те, що В. Липинський підійшов до реалізації своєї дипломатичної місії неординарно, налагодивши спочатку контакти в науковому середовищі Відня, а потім вже в дипломатичному. Справа в тому, що В. Липинський був визнаним на заході політичним та громадським діячем і істориком, а тому його призначення на посаду посла Української Держави «було кроком надзвичайно розсудливим та далекоглядним, враховуючи його прагнення до об'єднання українських земель» [6, с. 37-38]. Ще більш ємний та цілковито правдивий історико-політичний портрет В. Липинського можна знайти в працях Б. Яроша, який акцентує увагу на тому, що В. Липинський хоча і не був дипломатом за своїм фахом чи освітою, однак він був надзвичайним прихильником української державності і обстоював позицію необхідності існування «державного утворення на теренах Українських земель, в тому числі і тих, що входили до складу Австро-Угорщини» [7, с. 172-173].

Таким чином, перебування на посаді посла Української Держави В. Липинського у Відні, на противагу Ф. Штенгелю у Берліні, не дали суттєвих сьогочасних переваг, однак заклали підвалини для подальшого об’єднання українських земель. Австро-Угорщина ніколи не розглядала можливість існування потужного східного сусіда, а тому протистояла у цих питаннях навіть Німеччині, хоча, як демонструє практика ратифікації Брестської угоди, політикум Австро-Угорщини був надзвичайно розрізнений та переймався виключно проблемами єдності імперії.

Дипломатична місія у Відні загалом може вважатися досить ефективною, якщо розглядати ii в перспективі появи нових можливостей для реалізації геополітичної стратегії П. Скоропадського. «Водночас залишалося чимало зовнішньополітичних, зокрема територіальних проблем, неврегульованих через непоступливість позиції Австро-Угорщини. Незважаючи на підтримку гетьмана німецькою стороною $\mathrm{i}$ активну діяльність міністра Кюльмана та посла Мумма, які домагались обов'язкового виконання Брестської угоди щодо Холмщини, Відень порушив домовленості про їі передання Україні, більш того, відмовлявся ратифікувати Брестський договір Центральних держав з Україною, тому угода про автономію Галичини й Буковини не була реалізована» [8, с. 183].

Хоча загалом той факт, що Австро-Угорщина відмовиться від ратифікації Брестської угоди, був очевидним, а більш того передбачуваним. Тому основною метою діяльності В. Липинського у Відні слід вважати все ж таки обстоювання інтересів Української Держави $з$ метою розширення суверенітету на всі території проживання етнічних українців. Об'єднання українських земель, що перебували у складі Австро-Угорщини, а також частково у складі Румунії та Польщі В. Липинський ставив собі за першочергове завдання.

Для цього після свого призначення в якості посла в Австро-Угорщині 21.06.1918 року В. Липинський зі своїм радником I. ТокаржевськимКарашевичем та послом Української Держави в Болгарському Царстві О. Шульгіним провели «важливі зустрічі у Львові з визначними галицькими політичними діячами, керівниками української репрезентації в австрійському парламенті Костем Левицьким і Свгеном Петрушевичем, митрополитом греко-католицької церкви Андреєм Шептицьким» [8, с. 365]. Окремим напрямком роботи посольства В. Липинського була визначена опіка над «українцями - військовополоненими i біженцями на землях Габсбурзької імперії» [9].

Окремо слід звернути увагу на те, що П. Скоропадський доручив В. Липинському саме через Австро-Угорщину встановити та розширити зв'язки із Болгарським Царством та Османською Імперією.

Загалом Австро-Угорський вектор зовнішньополітичної стратегії Української Держави зводився скоріше до захисту українських інтересів від посягань європейських держав.

По-перше, місія посольства у Відні включала окрім спонукання Австро-Угорського уряду до ратифікації Брестської мирної угоди, також і до виконання iii іншими членами Четверного Союзу: Болгарією та Туреччиною.

По-друге, важливим, але так і нездійсненим, завданням виявилося протистояння територіаль- 
ним претензіям Румунії та Польщі. Перша, маючи підтримку Австро-Угорщини, претендувала на землі Буковини. Однак, захоплення міста Чернівці румунськими військами сталося лише після падіння Австро-Угорщини. Польська ж дипломатія виявилася потужнішою за українську, оскільки не лише протистояла ратифікації Австро-Угорщиною Брестської мирної угоди, але і висловлювала претензії на території Лемківщини, Посяння, Холмщини й Підляшшя. Окупація польськими військами цих територій відбулася в листопаді 1918 року після розпаду Австро-Угорщини.

По-третє, економічний зріз двосторонніх відносин між Українською Державою та Австро-Угорщиною постійно демонстрував панування інтересів останньої. Хоча посольство В. Липинського у Відні і було найчисленнішим із усіх закордонних представництв Української Держави, однак домогтися виконання всіх покладених завдань В. Липинський так і не зміг.

Разом із тим, даючи історичну оцінку реалізації австро-угорського геополітичного вектору, слід зауважити, що вихідні умови були надзвичайно складними. Українська Держава, яка фактично утворилася за результатами Першої Світової Війни, була новим суб'єктом міжнародних відносин, але намагалася реалізувати власний потенціал, враховуючи ресурси та геополітичне становище. В. Липинський досяг максимальних успіхів, враховуючи наявні ресурси та можливості Української Держави, однак він був фактично позбавлений підтримки Голови Ради Міністрів та гетьмана П. Скоропадського, які віддали перевагу Німеччині. Хоча саме В. Липинський, розуміючи падіння Австро-Угорщини, передбачив основні загрози територіальній цілісності України з боку Румунії та Польщі і намагався попередити окупацію західних земель Української Держави, однак в силу відсутності регулярної армії суто дипломатичні спроби не дали необхідного ефекту. Важливим здобутком дипломатів в Австро-Угорщині слід відзначити встановлення контактів із Болгарією та Туреччиною, що в подальшому відкрило нові можливості для міжнародних відносин Української Держави на тлі загрози агресії з боку Більшовицької Росії.

Насправді ж діяльність В. Липинського у Відні багато в чому сприяла порушенню рівноваги Четверного Союзу та реальній підтримці визвольного руху на українських землях у складі Австро-Угорщини. Наприклад, той факт, що саме В. Липинським було налагоджено перші дипломатичні контакти з Болгарським Царством та Туреччиною у Відні, засвідчують далекоглядність дипломата та складність завдання, яке перед ним стояло при очоленні власної дипломатичної місії.

Посольство в Болгарському Царстві очолив О. Шульгін, який був досить перспективним дипло- матом та якому дісталася незвичайна місія - поширення економічної та торговельної співпраці iз Болгарією і налагодження через цю країну торгівельних контактів із країнами півдня Європи. «Аналізуючи взаємини України з Болгарією, треба відзначити, що від самого початку вони склалися дуже добре. Приязне ставлення до України та гетьмана П. Скоропадського демонстрував болгарський цар Фердинанд, який був задоволений тим, що замість заборчої, імперіалістичної Росії, сусідом Болгарії по північному березі Чорного моря є Україна. Важливим аспектом українсько-болгарських відносин у цей період було поглиблення торговельно-економічних зв'язків, які істотно збільшили заплановані Брестським мирним договором обсяги поставок українських товарів у Болгарію» [10, с. 134-135]. Гетьман П. Скоропадський та Д. Дорошенко чітко усвідомлювали, що Болгарія $є$ однією із найбільш слабких у політичному сенсі країн із Четверного Союзу, а тому дипломатичний потенціал Української Держави дасть змогу реалізувати південно-європейський геополітичний вектор. Однак, відносини з Болгарією встановлювалися досить складно з організаційної точки зору, оскільки багато часу займало вирішення проблеми економічного співробітництва, пошуку найбільш оптимальних сфер для торгівлі тощо. Сама дипломатична місія на чолі з О. Шульгіним переймалася також проблемою ратифікації Брестської мирної угоди, але домагалася цього виключно після того, як таку ратифікацію здійснила Німеччина.

О. Шульгін, судячи 3 його політичної активності, мав і інші завдання гетьмана П. Скоропадського. По-перше, видається його надзвичайна хитрість у самому маршруті слідування із дипломатичною місією до Софії. 3 початку посол відвідує Відень, після того Белград, Бухарест і лише потім Софію. При цьому вже у Відні він обмінявся дипломатичними документами із послом Болгарії у Австро-Угорщині, а у Бухаресті, зустрічаючись iз представниками української інтелігенції, оголосив про свої наміри в Болгарії. Такі дії викликали невдоволення у дипломатичних колах Австро-Угорщини, яка вважала Болгарію своєю сферою впливу.

Натомість О. Шульгін одразу по прибуттю в Софію домігся «укладання двосторонньої угоди про торгівлю між Українською Державою i Болгарією. Усвідомлюючи брак часу, О. Шульгін волів не очікувати призначення з Києва офіційного консульства та окремого торговельного агента. Посольство переймалося також проблемою захисту прав біженців з України, опікою над військовополоненими українцями» [ 11, с. 30-31].

Крім того, як зауважує А. Папакін, «судячи 3 документів, одним 3 основних питань діяльності українського посольства в Болгарії були справи 
військовополонених. Колишні російські піддані, захоплені у полон у ході Першої світової війни, за умовами Брестського миру повинні були бути звільнені; болгарський уряд не перешкоджав цьому, але на перешкоді стали дії української сторони: затягування зі створення спеціальної комісії, відсутність військового аташе ген. Б. Бобровського, відсутність грошей» [12, с. 35]. «У підсумку О. Шульгін домігся визволення 3 полону й дозволу на повернення до Батьківщини 15 тис. військовиків-українців, що були зосереджені у Болгарії та на Балканах й переправлялися до Одеси через транзитний табір у Варні. Крім того, практично без ускладнень було розв'язано питання відновлення майнових і громадянських прав українських громадян у Болгарії та болгарських громадян в Українській Державі» [13, с. 55].

По-друге, дипломатична активність О. Шульгіна зводилася в Софії до активного захисту українських інтересів у питаннях румуно-українських відносин. О.Шульгін домагався підтримки Царя Болгарії Фердинанда I Кобура в питаннях можливої військової допомоги або можливих гарантій захисту кордонів Української Держави від Румунської агресії. Двосторонні відносини у військовій сфері підтримувалися і послом Болгарського Царства у Києві І. Шишмановим. Цікаво, що саме за допомогою I. Шишманова були укладені одні з перших економічних угод між Українською Державою та Болгарським Царством у військовій та продовольчій сферах. Більше того, саме Болгарія стала першою країною, яка відкрила своє представництво у Києві, визнавши при цьому незалежність Української Держави.

Реалізація геополітичної стратегії стосовно Туреччини розпочалася 3 призначення М. Левитського «першим тимчасовим представником України в Туреччині. Це рішення українського уряду було направлено Великому Візирові Талаату-паші листом від 8 квітня 1918 року. Туреччина також направила до Києва своє посольство. Першим послом став досвідчений дипломата Ахмет Мухтар Бей. Поруч із дипломатичною місією в Києві також було засновано консульські установи Туреччини в Харкові та Одесі. Зазначений період вважається провідними турецькими фахівцями ключовим у формуванні підвалин двосторонніх взаємин» $[14$, с. 28]. Насправді укладення Брест-Литовського мирного договору стало важливим кроком на шляху політичного та економічного єднання країн. Хоча їх історичне минуле було надзвичайно складним, на етапі Першої Світової війни Порта розглядалася вітчизняними дипломатами як можливий майданчик для контактів із країнами Антанти, оскільки Туреччина була слабкою у військовому плані і потерпала від поразок військ Антанти.
Усталеності в українсько-турецькі відносини привніс віденський період В. Липинського, який 22.08.1918 року «у Відні обмінявся ратифікаційними грамотами 3 представниками Османської Імперії. Українську сторону репрезентував В. Липинський, турецьку за підписом Магомета V - турецький посол у Відні Гусейн-Гільмі-Паша. Головою українського посольства в Туреччині ще в червні 1918 р. було призначено М. Суковкіна» [15, с. 172]. «Незважаючи на дуже складну ситуацію у країні (вихід з війни та присутність у Золотому Розі військових кораблів Антанти), турецький султан Магомет П'ятий прийняв українців із великими почестями. Він тепло привітав посла М. Суковкіна, потім особисто кожного $з$ членів представництва, заявивши, що «дуже радий був пізнати нас і бажає нам доброго життя в своїй державі» $[16$, с. 360$]$. Такий прийом і головне участь М. Суковкіна в офіційних заходах, що провадилися Османським двором, давала йому змогу встановити надзвичайно тісні контакти 3 турецькими торгівельними та політичними колами. Однак, коротка тривалість дипломатичної місії не дала необхідних результатів у контексті реалізації геополітичної стратегії гетьмана П. Скоропадського.

Більше того, як зауважує в своїх працях В. I. Головченко, «М. Суковкін до кінця не розумів значення Туреччини для Української Держави, намагаючись використовувати потенціал турецького султана Магомета П'ятого для політичного тиску на країни Четверного Союзу з метою послаблення окупаційного ярма на українську державність, а також в питаннях розбудови відносин із Кримом, а точніше в питанні приєднання території Кримського півострова до Української Держави» [17, c. 560-562]. Саме таку мету переслідував М. Суковкін, перебуваючи в Туреччині, оскільки кримське питання вже давно назріло для вирішення в українській метрополії, але для цього Україна потребувала союзників, одним із яких М. Суковкін бачив беззаперечно Туреччину, яка вже вийшла 3 війни, але прагнула реваншу за рахунок менших та слабших країн.

\section{Висновки.}

Таким чином, підсумовуючи внесок дипломатичного корпусу гетьманату в реалізації геополітичної стратегії П. Скоропадського, слід зауважити наступне.

По-перше, чітка зовнішньополітична доктрина так і не була вироблена за часів існування Української Держави. Власне, навіть сам П. Скоропадський чітко не визначав пріоритети зовнішньої політики, хоча і сконцентрував повноваження в сфері міжнародних відносин у своїх руках.

По-друге, аналіз дипломатичної активності МЗС та реального геополітичного становища Української Держави продемонстрували хиб- 
ність установлених напрямків та цілей, оскільки було знехтувано значенням російської загрози для українського суверенітету, а також значенням країн Антанти в умовах, коли стало зрозуміло, що поразка Четверного союзу в Першій Світовій Війні є неминучою.

По-третє, активність дипломатичного корпусу
Української Держави насправді принесла велику користь для становлення молодої держави в тих умовах, у яких відбулося іiі формування. Дипломатичні місії в Німеччині та Австро-Угорщині, а також посольство в Болгарії домоглися значних результатів у розширенні міжнародного визнання Української Держави.

\section{БІБІЛІОГРАФІЧНІ ПОСИЛАННЯ}

1. Останній гетьман: ювілейний збірник пам'яті Павла Скоропадського, 1873-1945 / відп. ред. О. Лупанов // Центр суспільних досліджень ім. В. Липинського, Ін-т укр. археографії АН України. - Київ: Академпрес, 1993. $397 \mathrm{c}$. 2. Кульчицький С. Гетьман Павло Скоропадський та Українська Держава 1918 року: наук. зб., присвячений 125 -річчю від народження Гетьмана Скоропадського та 80річчю проголошення Української Держави 1918 року / С. Кульчицький [та ін.]. - Київ, 1998. - 242 с.

3. Павло Скоропадський - останній гетьман України (до 140-річчя від дня народження) // Національна та історична пам’ять. - 2013. - № 7.

(Спецвипуск).

4. Осташко Т. В'ячеслав Липинський - історик, політик, дипломат / Т. Осташко // Україна дипломатична: науковий щорічник. - 2002. - № 3. - С. 656-659.

5. Нариси історії української революції 1917-1921 років / Ред. кол.: В. А. Смолій (голова) // НАН України. Інститут історії України. - Київ: НВП «Видавництво «Наукова думка» НАН України», 2012. - Кн. 1. - 390 с.

6. Білас Л. В'ячеслав Липинський - історик / Л. Білас // В'ячеслав Липинський: історико-політологічна спадщина і сучасна Україна (Студіі). - Київ; Філадельфія, 1994. - Т. 1. - С. 30-41.

7. В'ячеслав Липинський - ідеолог українського державотворення: Зб. наук. праць / Ред. Б. Ярош // НАН України. Ін-т політ. і етнонац. досліджень та ін. - Луцьк: Волин. обл. друк., 2001. - 188 с.

8. Дацків І. Б. Дипломатія українських національних урядів у захисті державності (1917-1923 pp.) - Рукопис: дис. ... доктора істор. наук: 07.00.02 / І. Б. Дацків. - Київ: Дипломатична академія України при МЗС України, 2010.

9. ЦДАВО України, ф. 3198, оп. 2, спр. 3, арк. 3. 2 Там само, спр. 2, арк. 1-4

10. Дацків І. Б. Дипломатичні заходи Гетьманату П. Скоропадського щодо міжнародного визнання і недоторканості кордонів України / І. Б. Дацків // Наукові записки Вінницького державного педагогічного університету ім. М. Коцюбинського. Серія: Історія. - 2008. - № XIV. - С. 133-136.

11. Павленко В. Українсько-болгарські взаємини 1918-1939рр. / В. Павленко - Київ: Інститут історії України НАН України, 1995.

12. Папакін А. Українські архівні документи з історії українсько-болгарських дипломатичних стосунків 19181920 pp. / А. Папакін // Славістична збірка. - Випуск 1: Збірка статей за матеріалами Перших Міжнародних наукових Соханівських читань (м. Київ, 18 листопада 2014 р.). - Київ, 2015.

13. Гай-Нижник П. П. Українсько-болгарські міждержавні і дипломатичні відносини: рік 1918-й / П. П. Гай-нижник // Гілея. - 2017. - Т. 125 - № 10. - С. 47-58.

14. Корсунський С. В. Українсько-турецькі відносини: минуле, сьогодення, завтра... / С. В. Корсунський // Зовнішня політика і дипломатія: погляд із XXI століття. - 2011. - № 17. - С. 24-31.

15. Дорошенко Д. Історія України 1917-1923 рр. / Д. Дорошенко. - Київ: Темпора, 2002. - Т. 2. - 351 с.

16. Головченко В. І. Суковкін Михайло Акінфійович // Українська дипломатична енциклопедія: [у 2-х т.] / В. I. Головченко. - Київ: Знання України, 2004. - Т. 2. - 812 с.

\section{REFERENCES}

1. Lupanov, O. (Eds.). (1993). Ostanniy het'man : yuvileynyy zbirnyk pam»yati Pavla Skoropads'koho, 1873-1945 [The last hetman: the jubilee collection of the memory of Pavlo Skoropadsky,1873-1945]. Center for Social Studies them V. Lypinsky, Institute of Ukr. Archeology of the Academy of Sciences of Ukraine. Kyiv: Akadempres [in Ukrainian].

2. Kul'chyts'kyy, S. et al. (1998). Het'man Pavlo Skoropads'kyy ta Ukrayins'ka Derzhava 1918 roku [Hetman Pavlo Skoropadsky and the Ukrainian State of 1918]. Nauk. zb., prysvyachenyy 125-richchyu vid narodzhennya Het'mana Skoropads'koho, ta 80-richchyu proholoshennya Ukrayins'koyi Derzhavy 1918 roku - scientific collection devoted to the 125th anniversary of the birth of Hetman Skoropadsky and 80-th anniversary of the proclamation of the Ukrainian state of 1918. Kyiv [in Ukrainian].

3. Pavlo Skoropads'kyy - ostanniy het'man Ukrayiny (do 140-richchya vid dnya narodzhennya) [Pavlo Skoropadsky the last hetman of Ukraine (to the 140th anniversary of his birthday]. (2013). National and historical memory, 7 (Special issue) [in Ukrainian]. 
4. Ostashko, T. (2002). Vyacheslav Lypyns'kyy - istoryk, polityk, dyplomat [

Vyacheslav Lipinsky is a historian, politician, diplomat]. Diplomatic Ukraine: Scientific Yearbook, 3, 656-659 [in Ukrainian].

5. Smoliy, V.A. (Eds.). (2012). Narysy istoriyi ukrayins'koyi revolyutsiyi 1917-1921 rokiv [Essays on the history of the Ukrainian revolution of 1917-1921]. National Academy of Sciences of Ukraine. Institute of History of Ukraine. (Vol. 1). Kyiv: NVP «Vydavnytstvo Naukova dumka NAN Ukrayiny» [in Ukrainian].

6. Bilas, L. (1994). Vyacheslav Lypyns'kyy - istoryk [Vyacheslav Lipinsky is a historian]. Vyacheslav Lipinsky: Historical and Political Heritage and Modern Ukraine. (Vol. 1.), (pp. 30-41). Kyiv; Filadelfiya [in Ukrainian].

7. Yarosh, B. (2001). Vyacheslav Lypyns'kyy - ideoloh ukrayins'koho derzhavotvorennya [Vyacheslav Lipinsky is an ideologue of the Ukrainian state-building]. Lutsk: Volyn. obl. druk. [in Ukrainian].

8. Datskiv, I.B. (2010). Dyplomatiya ukrayins'kykh natsional'nykh uryadiv u zakhysti derzhavnosti (1917-1923 rr.) [Diplomacy of the Ukrainian National Governments in the Defense of the Statehood (1917-1923)]. Doctor's thesis. Kyiv: Diplomatic Academy of Ukraine under the Ministry of Foreign Affairs of Ukraine [in Ukrainian].

9. TsDAVO Ukrayiny, f. 3198, op. 2, spr. 3, ark. 3. 2 Tam samo, spr. 2, ark. 1-4 [in Ukrainian].

10. Datskiv, I.B. (2008). Dyplomatychni zakhody Het'manatu P. Skoropads'koho shchodo mizhnarodnoho vyznannya i nedotorkanosti kordoniv Ukrayiny [Diplomatic measures of Hetmanate P. Skoropadsky concerning the international recognition and inviolability of the borders of Ukraine]. Scientific notes of M. Kotsyubinsky Vinnitsa State Pedagogical University. History, XIV, 133-136 [in Ukrainian].

11. Pavlenko, V. (1995). Ukrayins'ko-bolhars'ki vzayemyny 1918-1939 rr. [Ukrainian-Bulgarian relations 1918-1939]. Kyiv: Instytut istoriyi Ukrayiny NAN Ukrayiny [in Ukrainian].

12. Papakin, A. (2015). Ukrayins'ki arkhivni dokumenty z istoriyi ukrayins'ko-bolhars'kykh dyplomatychnykh stosunkiv 1918-1920 rr. [Ukrainian archival documents on the history of Ukrainian-Bulgarian diplomatic relations 1918-1920].

Slavic collection. Issue 1: Collection of articles on the materials of the First International Scientific Sokhaniv Readings (Kyiv, November 18, 2014). Kyiv [in Ukrainian].

13. Hay-Nyzhnyk, P.P. (2017). Ukrayins'ko-bolhars'ki mizhderzhavni i dyplomatychni vidnosyny: rik 1918-y [UkrainianBulgarian intergovernmental and diplomatic relations: the year of 1918]. Hileya, 125 (10), 47-58 [in Ukrainian].

14. Korsunskyy, S.V. (2011). Ukrayins'ko-turets'ki vidnosyny: mynule, s'ohodennya, zavtra... [Ukrainian-Turkish Relations: Past, Present, Tomorrow...]. Foreign Policy and Diplomacy: A View from the 21st Century, 17, 24-31[in Ukrainian].

15. Doroshenko, D. (2002). Istoriya Ukrayiny 1917-1923 rr. [History of Ukraine 1917-1923]. Kyiv: Tempora [in Ukrainian].

16. Holovchenko, V.I. (2004). Sukovkin Mykhaylo Akinfiyovych [Sukovkin Mikhail Akinfiyovych]. Ukrainian Diplomatic Encyclopedia. (Vols. 1-2). Kyiv: Znannya Ukrayiny [in Ukrainian].

\section{Приходько Микола}

Аспірант

Національний Педагогічний Університет ім. М. П. Драгоманова

02000, м. Київ, вул. Пирогова, 9

\section{Prykhodko Mykola}

Post-graduate-student

National Pedagogical Dragomanov University

9, Pirogova str., Kyiv, 02000, Ukraine

ORCID: 0000-0002-7428-8540Ｅmail: prihod@ukr.net

Цитування: Приходько М. М. Внесок дипломатичного корпусу Гетьманату в реалізацію геополітичної стратегії Павла Скоропадського / М. М. Приходько // Науково-теоретичний альманах «Грані». - 2018. T. 21. - № 3. - C. 63-69.

Citation: Prykhodko, M.M. (2018). Vnesok dyplomatychnoho korpusu Hetmanatu v realizatsiiu heopolitychnoi stratehii Pavla Skoropadskoho [Contribution of the Hetmanate's diplomatic corps in implementing the geopolitical strategy of Pavlo Skoropadsky]. Scientific and theoretical almanac "Grani», 21(3), 63-69. 